\title{
Rodent helminths in fragmented Atlantic Forest areas in the western region of the state of Paraná
}

\author{
Helmintos de roedores em áreas fragmentadas de Mata Atlântica na região \\ Oeste do Estado do Paraná
}

\author{
Danise Benatti; Luis Felipe Andrietti²; José Flávio Cândido Júnior²; Alexandre Vogliotti; \\ Marcela Figueirêdo Duarte Moraes ${ }^{1}$; José Hairton Tebaldi1; Estevam Guilherme Lux Hoppe ${ }^{1 *}$ (D) \\ 'Laboratório de Enfermidades Parasitárias dos Animais Domésticos - LabEPar, Departamento de Patologia, Reprodução e Saúde \\ Única, Faculdade de Ciências Agrárias e Veterinárias - FCAV, Universidade Estadual Paulista - UNESP, Jaboticabal, SP, Brasil \\ ${ }^{2}$ Universidade Estadual do Oeste do Paraná - UNIOESTE, Cascavel, PR, Brasil \\ ${ }^{3}$ Universidade Federal da Integração Latino-Americana - UNILA, Foz do Iguaçu, PR, Brasil
}

\begin{abstract}
How to cite: Benatti D, Andrietti LF, Cândido Júnior JF, Vogliotti A, Moraes MFD, Tebaldi JH, et al. Rodent helminths in fragmented Atlantic Forest areas in the western region of the state of Paraná. Braz J Vet Parasito/ 2021; 30(3): e009521. https://doi.org/10.1590/ S1984-29612021058
\end{abstract}

\begin{abstract}
Rodents are small mammals that can be parasitized by various helminths. This study aimed to identify and describe the ecological indicators of infection in rodents captured in fragments of the Atlantic Forest in the western region of Paraná State, Brazil. Sixty-eight specimens of five rodent species were collected, necropsied, and inspected in search of helminths. The parasites were stored in $70 \%$ ethanol, morphologically identified, and counted for calculation of infection indicators. Fourteen species of helminths and one species of Crustacea were recorded: ten in Akodon montensis, four in Mus musculus, two in Thaptomys nigrita, two in Oligoryzomys nigripes, and one in Euryoryzomys russatus. The registered species of parasites were: Rodentolepis akodontis, Angiostrongylus sp., Protospirura numidica criceticola, Trichuris navonae, Syphacia alata, Syphacia criceti, Syphacia evaginata, Trichofreitasia lenti, Stilestrongylus aculeata, Stilestrongylus eta, Stilestrongylus gracielae, Stilestrongylus franciscanus, Stilestrongylus moreli, Stilestrongylus sp., and Pentastomida gen. sp. A positive correlation between the intensity of infection of $T$. navonae and T. lenti was observed with the body condition index of the host $A$. montensis. For all species, this study represents a new register of locality, and for eight of them a new host.
\end{abstract}

Keywords: Rodentia, Nematoda, Cestoda, fragmentation of habitat.

\begin{abstract}
Resumo
Roedores são pequenos mamíferos que podem ser parasitados por uma diversidade de helmintos. Este estudo teve como objetivo identificar e descrever os indicadores ecológicos de infecção por helmintos, em roedores capturados em fragmentos de Mata Atlântica, na região Oeste do Estado do Paraná, Brasil. Sessenta e oito animais foram coletados, necropsiados e inspecionados em busca de helmintos. Os parasitas foram armazenados em etanol 70\%, identificados morfologicamente e contados para o cálculo dos indicadores de infecção. Quatorze espécies de helmintos e uma espécie de crustáceo foram registradas: dez em Akodon montensis, quatro em Mus musculus, duas em Thaptomys nigrita, duas em Oligoryzomys nigripes e uma em Euryoryzomys russatus. As espécies de parasitas registradas foram: Rodentolepis akodontis, Angiostrongylus sp., Protospirura numidica criceticola, Trichuris navonae, Syphacia alata, Syphacia criceti, Syphacia evaginata, Trichofreitasia lenti, Stilestrongylus aculeata, Stilestrongylus eta, Stilestrongylus gracielae, Stilestrongylus franciscanus, Stilestrongylus moreli, Stilestrongylus sp., e Pentastomida gen. sp. Uma correlação positiva entre a intensidade parasitária de T. navonae e T. lenti foi observada com o índice de condição corporal do hospedeiro A. montensis. Para todas as espécies, este estudo representa um novo registro de localidade, e para oito delas um novo hospedeiro.
\end{abstract}

Palavras-chave: Rodentia, Nematoda, Cestoda, fragmentação de habitat.

Received May 21, 2021. Accepted June 1, 2021.

*Corresponding author: Estevam Guilherme Lux Hoppe. E-mail: Iux.hoppe@unesp.br

This is an Open Access article distributed under the terms of the Creative Commons Attribution License, which permits unrestricted use distribution, and reproduction in any medium, provided the original work is properly cited. 


\section{Introduction}

The Atlantic Forest is one of the biomes that suffers most in the world from the processes of habitat loss and fragmentation (Myers et al., 2000; Mittermeier et al., 2005). Most Atlantic Forest remnants are small and surrounded by an anthropic matrix (Ribeiro et al., 2009). This scenario changes the natural structure of populations and metapopulations of small mammals, favoring the emergence of small and isolated populations (Fahrig, 2003), as well as increasing proximity to human and domestic animal populations (Silva et al., 2018).

Rodents are a megadiverse group of mammals, representing $40 \%$ to $45 \%$ of mammalian species, occupying different biomes (Patton et al., 2015). These animals can act as reservoirs of parasites causing zoonotic diseases (Froeschke \& Matthee, 2014), and their eventual proximity to human settlements represent a link between wild and domestic environments, increasing the risk of pathogen transmission to domestic animals and humans (Fundação Nacional de Saúde, 2002; Klimpel et al., 2007; Reperant et al., 2009).

Thus, it is necessary to understand parasitism in rodents living in small fragmented areas of the Atlantic Forest in western Paraná State, Brazil. We investigate the influence of host species, sex, and body condition on helminth parasitic intensity and prevalence, and the influence of the landscape on the structural patterns of the helminth community.

\section{Materials and Methods}

\section{Study area}

The research was developed in the remaining Atlantic Forest areas in the state of Paraná, Brazil, comprising the cities of Cascavel and Corbélia. These areas are located in the third plateau of the state, in the western region of Paraná, with an altitude varying around $781 \mathrm{~m}$. The climate is humid subtropical, with an average annual temperature of approximately $19^{\circ} \mathrm{C}$. The average maximum temperature in January is $28.6^{\circ} \mathrm{C}$, and in July the average minimum is $11.2^{\circ} \mathrm{C}$, with the occurrence of frosts. The characteristic vegetation is Semideciduous Seasonal Forest (IBGE, 2017).

The remaining Atlantic Forest areas in the region are closely linked to anthropic influences, since the growing demand for food has transformed the surroundings of the small fragments into agricultural landscapes for grain production and dairy farming (Myers et al., 2000). This condition has led to the presence of domestic animals inside and wild animals outside these fragments, since, due to food shortages, rodents have expanded their colonies between and around plantations and peri-domiciliary facilities, and in the home itself (Fundação Nacional de Saúde, 2002; Silva et al., 2018).

\section{Rodent collection}

The samples were collected in five small fragments of remaining Atlantic Forest area near the municipalities of Cascavel ( $\left.24^{\circ} 57^{\prime} 21^{\prime \prime S}, 53^{\circ} 27^{\prime} 18^{\prime \prime} \mathrm{O}\right)$ and Corbélia ( $\left.24^{\circ} 47^{\prime} 56^{\prime \prime} \mathrm{S}, 53^{\circ} 18^{\prime} 25^{\prime \prime} \mathrm{W}\right)$ in the western region of the state of Paraná. Fragment 1, with an area of 73 ha, Fragment 2, with 96 ha, Fragment 3, covering an area of 28 ha, Fragment 4, with only 11 ha, and Fragment 5, 24 ha of total area (Figure 1).

The blocks are composed of three parallel trapping lines, positioned at the intersection (interface) of the fragment with the adjacent agricultural matrix, 100m away towards the interior of the fragment and the matrix. Each line contained 10 traps set $20 \mathrm{~m}$ apart from each other, and one pitfall trap, totaling $200 \mathrm{~m}$ of transept.

Sherman-type $(32.4 \times 11.7 \times 14.2 \mathrm{~cm})$, Tomahawk $(29.5 \times 11 \times 10.5 \mathrm{~cm})$, and pitfall $(60 \mathrm{~L}$ buckets and canvas barrier $50 \mathrm{~cm}$ high by $18 \mathrm{~m}$ long) traps were used. The traps were baited with slices of pineapple, a mixture of paçoca (ground peanuts and sugar), oats, grated tuna, and bacon as bait, and were inspected every morning (Mangini \& Nicola, 2006).

The sampling occurred simultaneously, over five consecutive nights, in the months of September, November, and December of 2017, and January and February of 2018, corresponding to the initial and late stages of soy cultivation, and April, June, July, and August of 2018, corresponding approximately to the initial and late stages of corn cultivation in the region.

Captured animals were transported to the Laboratory of Metabolism and Human and Animal Physiology of UNIOESTE (Universidade Estadual do Oeste do Paraná - Campus Cascavel), where they were sacrificed by overdose of the volatile anesthetic isoflurane (Brasil, 2012). 


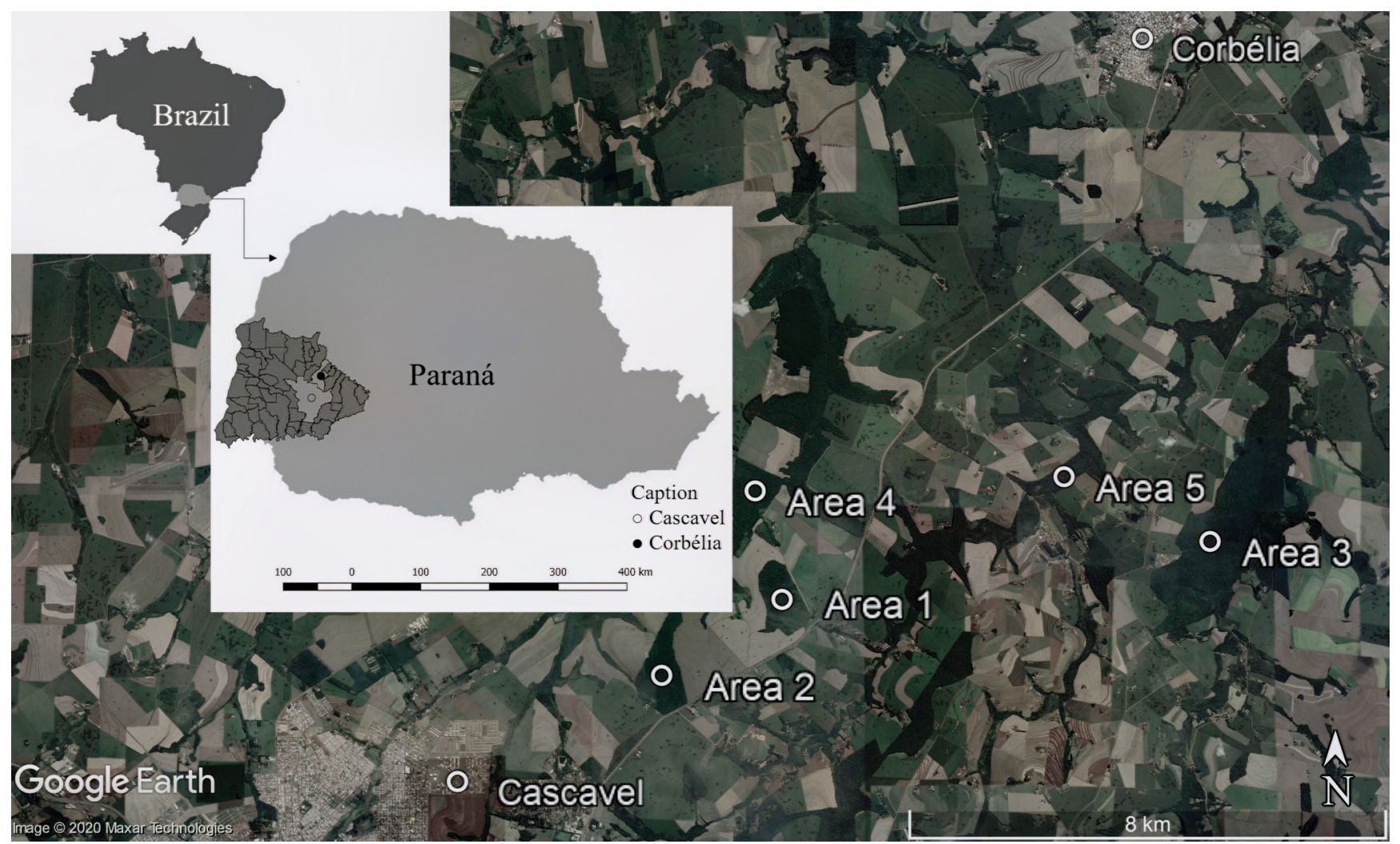

Figure 1. Small rodent sampling locations, from 2017 to 2018, in small Atlantic Forest fragments in western Paraná, Brazil.

Species identification was done through analysis of the guard hairs, by cytogenetics and by analyzing the external and cranial morphology (Quadros \& Monteiro Filho 2006; Bonvicino et al., 2008). The skin and skull of the specimens were preserved by taxidermy and skeleton, according to Reis et al. (2010). At necropsy, sex, weight, head-to-tail length, tail length, hind limb length, ear length, and width were recorded for each host, according to Reis et al. (2010).

Each animal was evaluated individually, and all abdominal cavity organs were removed en bloc, together with the diaphragm muscle, and stored individually in identified plastic bags at $-20^{\circ} \mathrm{C}$. The material was then sent to the Laboratory of Parasitic Diseases (LabEPar/UNESP-FCAV), Jaboticabal/SP, for parasitological assessment. The animal captures were authorized by the Instituto Chico Mendes de Conservação da Biodiversidade (SISBIO License 59597-1). All the procedures adopted were approved by the Ethics and Animal Use Committee/UNESP - Jaboticabal/SP (Protocol $n^{\circ}$ 006060/19) and were performed in accordance with international standards.

\section{Parasitological Necropsy}

Helminth collection

Parasitological necropsies were performed in LabEPar, where the anatomical segments of the digestive tract (esophagus, stomach, small intestine, and large intestine), trachea, heart, lung, liver, spleen, and kidneys were sectioned separately in Petri dishes and the contents were analyzed with a stereoscopic microscope for harvesting the helminths, which were later fixed and conserved in $70 \%$ ethanol.

\section{Helminth taxonomic identification}

The helminths were diaphanized in $80 \%$ acetic acid and, if necessary, diaphanized in beech creosote on temporary slides for optical microscopy studies. Taxonomic identification was based on 10 individuals of each sex (dioecious species), 10 adult individuals (monoecious species), or the maximum number of individuals available. To obtain morphometric and morphological characteristics, an Olympus BX-51 microscope with a Q-Color 3 digital camera 
was used and the images were processed by Image-Pro Plus 4. Identifications were based on keys such as described by Travassos (1917), Yamaguti (1963), Rêgo (1967), Vicente et al. (1997), Anderson et al. (2009), and additional literature. Vouchers were deposited in the Collection Oswaldo Cruz Institute (CHIOC/Fiocruz) and additional types were kept in the collection of the LabEPar, FCAV/Unesp.

\section{Analysis of the data}

After identification and counting, a descriptive analysis of indicators of parasite infection, such as prevalence, mean intensity, and mean abundance, was performed according to Bush et al. (1997). The host body condition index was determined by a comparison of the mass $(\mathrm{g})$ and total length $(\mathrm{cm})(\mathrm{ICC}=\mathrm{g} / \mathrm{cm})$ (Schulte-Hostedde et al., 2005). Only adult specimens were considered for this analysis. Prior to statistical analysis, data distribution was analyzed using the Kolmogorov-Smirnov test. Data with non-normal distributions, were analyzed with non-parametric tests. Fisher's exact test was applied to evaluate the relationship between the sex of the hosts, $A$. montensis and M. musculus, and the prevalence of each helminth. The Mann-Whitney test was used to verify the relationship between parasitic intensity and sex in A. montensis and M. musculus and parasitic intensity and landscape (border and fragment), only in A. montensis. Spearman's correlation coefficient was used to verify the relationship between the body condition index and the average parasitic intensity by parasite species. The coefficient of similarity of Jaccard was used to quantify the similarity of helminth communities between the different hosts ( $A$. montensis, $O$. nigripes, and $M$. musculus) and the influence of the landscape under the helminth fauna of $A$. montensis (performed only in this host due to the number of samples). All tests were performed using GraphPad Prism 7.04 software with $\mathrm{P}$ adjusted to 0.05 .

\section{Results}

We collected 68 rodents, representing five species of the Rodentia order: 40 Akodon montensis (25 Border - 15 Fragment), 20 Mus musculus (Plantation), five Oligoryzomys nigripes (3 Border - 2 Fragment), two Thaptomys nigrita (1 Border - 1 Fragment), and one Euryoryzomys russatus (Fragment). Sixty-five rodents were parasitized by at least one helminth species. A total of 4543 helminths were recovered, representing 15 species of three Phyla (Figure 2, Tables 1 and 2). Monoxenous parasites were predominant in all rodents analyzed. Morphometric data on the diagnosed species are listed on Table 3.

All analyzed $A$. montensis were parasitized by helminths. The most frequent species in this host was the trichostrongylid Stilestrongylus gracielae $(70 \%, 28 / 40)$. The less frequent species were the cestode Rodentolepis akodontis (5\%) (1/40) parasitizing the small intestine, Angiostrongylus sp. (5\%) (1/40) parasitizing the lung, and a species of Pentastomida gen. sp. (5\%) (1/40), in the form of an encysted nymph in the liver.

Ninety percent of Mus musculus (18/20) were parasitized by four species of helminths. The most frequent species, diagnosed in $85 \%$ of the rodents, was Stilestrongylus aculeata (14/20). Syphacia evaginata and Rodentolepis akodontis were the least diagnosed species, infecting $30 \%(6 / 20)$ of the analyzed hosts.

Eighty percent of the Oligoryzomys nigripes (4/5) were diagnosed with helminths, $40 \%(2 / 5)$ of the rodents were parasitized by Trichofreitasia lenti and Stilestrongylus franciscanus, parasitizing the bile duct and the small intestine, respectively. Analyzed Thaptomys nigrita were parasitized by helminths. The most frequent species, diagnosed in $100 \%$ of the animals, was Stilestrongylus sp., followed by the oxyurid Syphacia criceti, diagnosed in 50\% (1/2) of the hosts studied. Euryoryzomys russatus was parasitized by the trichostrongylid Stilestrongy/us moreli.

The highest mean helminth richness was observed in A. montensis (total richness 10 and mean richness 2.77). The trichostrongylids presented higher abundance and mean parasitic intensity, followed by the oxyurid species. The less abundant species were Pentastomida gen. sp. (nymph), Angiostrongylus sp., P. numidicola criceticola, T. navonae, and R. akodontis.

An intermediate positive correlation was observed between body condition index and mean parasitic intensity involving the nematodes Trichofreitasia lenti $\left(r s^{1}=0.415 ; \mathrm{P}=0.0118\right)$ and Trichuris navonae $(r s=0.477 ; \mathrm{P}=0.0032)$ in A. montensis. The interactions between: the sex of the hosts and the prevalence of each helminth, was only analyzed in A. montensis and M. musculus, due to the number of samples; parasitic intensity and landscape (border/fragment) in A. montensis; body condition index and total parasitic intensity by species; showed no statistical differences. Jaccard's index showed a low similarity (0.16) between the infra-communities of parasites in the hosts $A$. montensis,

\footnotetext{
Spearman correlation coefficient
} 

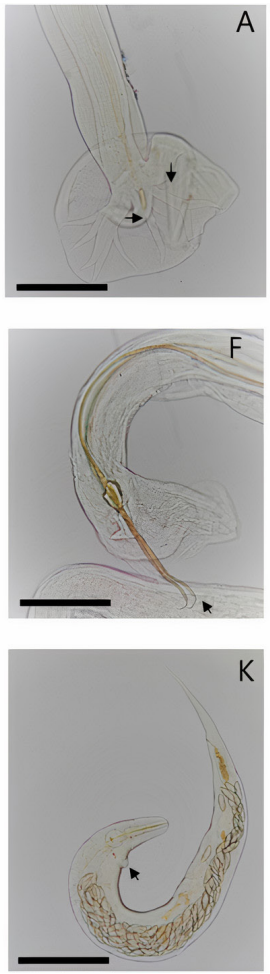
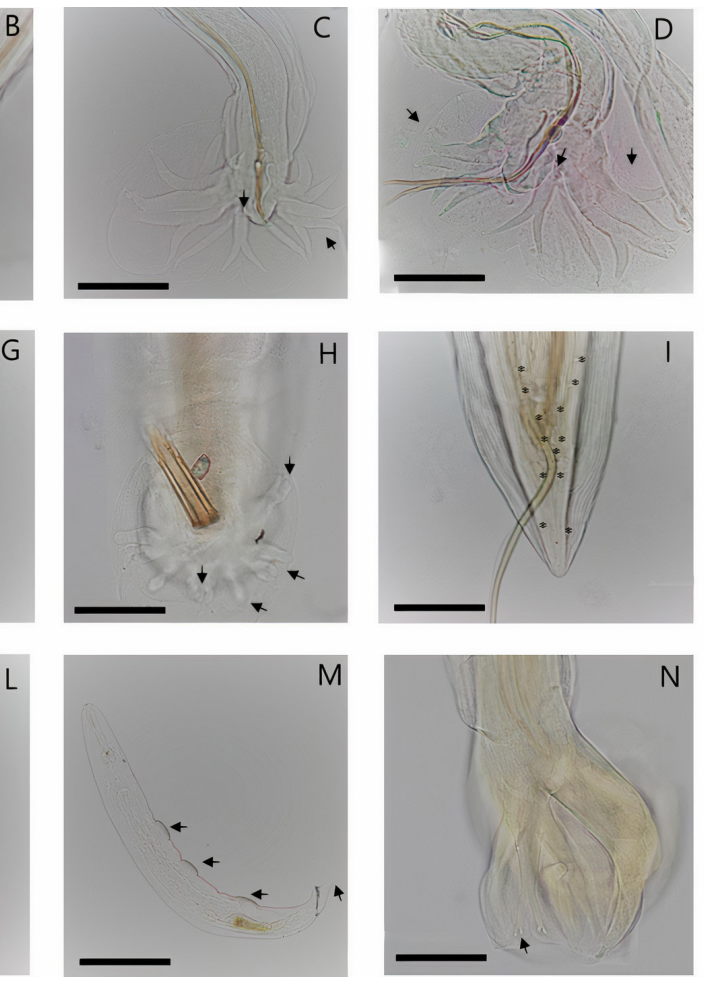
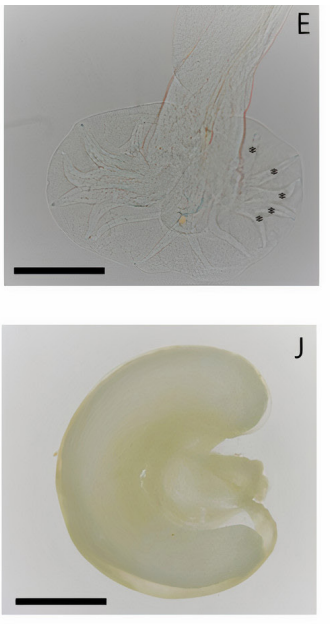

N

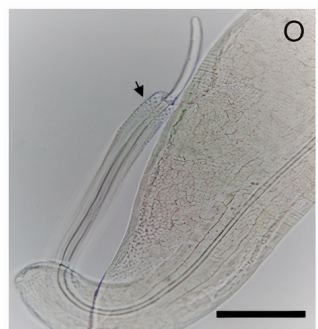

Figure 2. Parasites diagnosed in rodents from small Atlantic Forest fragments in Paraná State, Brazil. (A) Stilestrongylus franciscanus, externo-dorsal rays are asymmetrical, right external-dorsal ray is thin, arising from proximal third of dorsal ray, the left one is robust, arising at base from dorsal ray, both are longer than the dorsal ray (Scale 50 um); (B) Stilestrongylus sp. markedly asymmetrical caudal bursa hypertrophied genital cone (Scale 50 $\mu \mathrm{m})$; (C) Stilestrongylus eta, asymmetric caudal bursa, more developed right lobe, thin ray 8 emerging from the base of the dorsal trunk. (Scale 50 um); (D) Stilestrongylus aculeata, asymmetric caudal bursa, both externo-dorsal rays originate subsymmetrically at the base of the dorsal part of the trunk, but the origin of the left extrerno-dorsal ray is more proximal than the right. (Scale $50 \mu \mathrm{m})$; (E) Stilestrongylus gracielae, asymmetric caudal bursa with hypertrophied right lobe, type 1-4 pattern, rays 2 appearing first from the trunk than rays 2 to 6 (Scale $50 \mu m$ ); (F) Stilestrongylus moreli, caudal bursa strongly asymmetric, long and tapered spicules with a curvature in the final portion. (Scale $50 \mu \mathrm{m}) ;(\mathbf{G})$ Rodentolepis akodontis, scolex with four suckers without spines, rostellum armed with 20 to 28 hooks (Scale $50 \mu \mathrm{m}$ ); (H) Angiostrongylus sp. fused ventral bursal rays, except at the tips, ventro-lateral rays slightly longer than the ventro-ventral rays, the postero-lateral and medio-lateral rays were fused in the proximal half and separated from the externo-lateral rays after appearance, forming a common trunk, short dorsal bursal ray, ending in tip (Scale 50 $\mathrm{mm}$ ); (I) Protospirura numidica criceticola, present four pairs of pre-cloacal papillae and one unpaired papilla at the anterior edge of the cloacal opening, two large pairs of

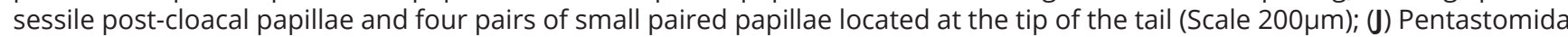

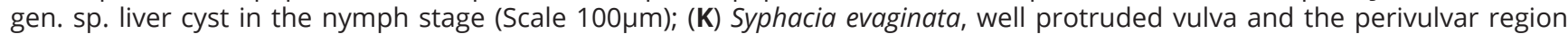
ornamented with a series of cuticular ridges (Scale $200 \mu \mathrm{m}$ ); (L) Syphacia alata, presence of three equidistant ventral mamelons, tail relatively long (Scale $200 \mu \mathrm{m}) ;(\mathbf{M})$ Syphacia criceti, presence of mamelons in addition to a spicule, and a gubernacule with the presence of an accessory hook. (Scale 100 $\mu \mathrm{m}) ;(\mathbf{N})$ Trichofreitasia lenti, sub-symmetrical caudal bursa, type 2-2-1, dorsal ray divided at mid-length into two branches, each branch divided into two subequal sub-branches, (Scale 50 $\mu$ m); (0) Trichuris navonae, males without spicular tube, proximal cloacal tube united laterally to distal cloacal tube, cylindrical and spiny spicular sheath (Scale $100 \mu \mathrm{m})$.

M. musculus, and 0 . nigripes, and a high similarity (0.9) between the landscapes in the rodent $A$. montensis, a test performed only in this host due to the number of samples.

\section{Discussion}

The helminthfauna found in this work shows similarities in the composition of the species in relation to those reported in Brazil and Argentina. Nematoda was the most frequent group in this study. Several authors have reported the same findings for other working areas (Cerrado savanna, Pampa grasslands, Caatinga shrubland), and for the same or other small mammal species (Gomes et al., 2003; Navone et al., 2009; Robles, 2011; Simões et al., 2012; Panisse et al., 2017; Hancke \& Suárez, 2018; Cardoso et al., 2019). 
Table 1. Prevalence $(P)$, mean abundance $(A)$, mean intensity $(\mathrm{MI})$, and range intensity $(\mathrm{RI})$ of rodent parasites in small Atlantic Forest fragments in western Paraná, Brazil.

\begin{tabular}{|c|c|c|c|c|c|c|c|c|c|c|c|c|c|c|c|c|}
\hline & \multirow{3}{*}{$\begin{array}{l}\text { Site of } \\
\text { infection }\end{array}$} & \multirow{2}{*}{\multicolumn{3}{|c|}{$\begin{array}{c}\text { Akodon montensis } \\
\qquad(n=40)\end{array}$}} & \multirow{2}{*}{\multicolumn{3}{|c|}{$\frac{\text { Oligoryzomys nigripes }}{(n=5)}$}} & \multirow{2}{*}{\multicolumn{3}{|c|}{$\begin{array}{c}\text { Thaptomys nigrita } \\
(n=4)\end{array}$}} & \multirow{2}{*}{\multicolumn{3}{|c|}{$\begin{array}{c}\begin{array}{c}\text { Euryoryzomys } \\
\text { russatus }\end{array} \\
(n=1)\end{array}$}} & \multirow{2}{*}{\multicolumn{3}{|c|}{$\begin{array}{c}\text { Mus musculus } \\
\text { (n=20) }\end{array}$}} \\
\hline & & & & & & & & & & & & & & & & \\
\hline & & P (\%) & A & MI (RI) & P (\%) & A & MI (RI) & P (\%) & A & MI (RI) & P (\%) & A & MI (RI) & P (\%) & A & MI (RI) \\
\hline \multicolumn{17}{|l|}{ Cestoda } \\
\hline $\begin{array}{l}\text { Rodentolepis } \\
\text { akodontis } \\
\text { (CHIOC 38790) }\end{array}$ & SI & 5 & 0.1 & $2(2)$ & - & - & - & - & - & - & - & - & - & 30 & 1.55 & $\begin{array}{c}5.16 \\
(3-10)\end{array}$ \\
\hline \multicolumn{17}{|l|}{ Nematoda } \\
\hline $\begin{array}{l}\text { Angiostrongylus sp. } \\
\text { (CHIOC 38791) }\end{array}$ & L & 5 & 0.1 & $4(4)$ & - & - & - & - & - & - & - & - & - & - & - & - \\
\hline $\begin{array}{c}\text { Protospirura } \\
\text { numidica criceticola } \\
\text { (CHIOC 38793) }\end{array}$ & $\mathrm{S}$ & 10 & 0.12 & $\begin{array}{l}1.25 \\
(1-2)\end{array}$ & - & - & - & - & - & - & - & - & - & - & - & - \\
\hline $\begin{array}{l}\text { Trichofreitasia lenti } \\
\text { (CHIOC 38904) }\end{array}$ & B & 55 & 5.58 & $\begin{array}{c}10.1 \\
(1-38)\end{array}$ & 40 & 9.2 & $\begin{array}{c}23 \\
(5-41)\end{array}$ & - & - & - & - & - & - & - & - & - \\
\hline $\begin{array}{c}\text { Stilestrongylus } \\
\text { aculeata (CHIOC } \\
38795)\end{array}$ & SI & 30 & 19.3 & $\begin{array}{c}64.5 \\
(16-116)\end{array}$ & - & - & - & - & - & - & - & - & - & 85 & 23.5 & $\begin{array}{c}27.7 \\
(1-201)\end{array}$ \\
\hline $\begin{array}{l}\text { Stilestrongylus eta } \\
\text { (CHIOC 38796) }\end{array}$ & SI & 45 & 24.1 & $\begin{array}{c}53.5 \\
(6-204)\end{array}$ & - & - & - & - & - & - & - & - & - & - & - & - \\
\hline $\begin{array}{l}\text { Stilestrongylus } \\
\text { franciscanus } \\
\text { (CHIOC 38797) }\end{array}$ & SI & - & - & - & 40 & 57 & $\begin{array}{c}142.5 \\
(120-165)\end{array}$ & - & - & - & - & - & - & - & - & - \\
\hline $\begin{array}{c}\text { Stilestrongylus } \\
\text { gracielae (CHIOC } \\
38798)\end{array}$ & SI & 70 & 29.2 & $\begin{array}{c}41.7 \\
(2-202)\end{array}$ & - & - & - & - & - & - & - & - & - & - & - & - \\
\hline $\begin{array}{l}\text { Stilestrongylus } \\
\text { kaaguyporai } \\
\text { (CHIOC 38799) }\end{array}$ & SI & - & - & - & - & - & - & - & - & - & 100 & 13 & $13(13)$ & - & - & - \\
\hline $\begin{array}{l}\text { Stilestrongylus sp. } \\
\text { (CHIOC 38794) }\end{array}$ & SI & - & - & - & - & - & - & 100 & 21.5 & $\begin{array}{l}21.5 \\
(9-34)\end{array}$ & - & - & - & - & - & - \\
\hline Trichuris navonae & C & 37,5 & 0.82 & $2.2(1-6)$ & - & - & - & - & - & - & - & - & - & - & - & - \\
\hline $\begin{array}{l}\text { Syphacia alata } \\
\text { (CHIOC 38800) }\end{array}$ & C & 25 & 3.1 & $\begin{array}{c}12.4 \\
(1-27)\end{array}$ & - & - & - & - & - & - & - & - & - & - & - & - \\
\hline $\begin{array}{l}\text { Syphacia criceti } \\
\text { (CHIOC 38901) }\end{array}$ & C & - & - & - & - & - & - & 50 & 0.5 & $1(1)$ & - & - & - & 50 & 11.5 & $\begin{array}{c}23 \\
(6-67)\end{array}$ \\
\hline $\begin{array}{l}\text { Syphacia evaginata } \\
\text { (CHIOC 38902) }\end{array}$ & C & - & - & - & - & - & - & - & - & - & - & - & - & 30 & 6.2 & $\begin{array}{c}20.5 \\
(8-48)\end{array}$ \\
\hline \multicolumn{17}{|l|}{ Pentastomida } \\
\hline $\begin{array}{l}\text { Petastomida } \\
\text { gen. sp. (nymph) } \\
\text { (CHIOC 38787) }\end{array}$ & $\mathrm{Li}$ & 5 & 0.05 & $1(1)$ & - & - & - & - & - & - & - & - & - & - & - & - \\
\hline
\end{tabular}

SI, Small intestine; L, Lung; S, Stomach; C, Cecum; Li, Liver; Bile duct, B.

The total helminth richness observed was similar when compared to that reported in other studies conducted in Brazil; Simões et al. (2011) described that $A$. montensis was parasitized by twelve helminth species in the state of Rio de Janeiro. In the state of Santa Catarina; Boullosa et al. (2019) reported six species of helminths in $A$. montensis and two species in O. nigripes. Gomes et al. (2003) reported two species of helminths in Rio de Janeiro state, and Cardoso et al. (2018) reported a total richness of six species of parasites in A. montensis and two in O. nigripes in a preserved area of the Atlantic Forest in the same State. Guimarães et al. (2014) diagnosed three species of helminths in M. musculus in the state of Sergipe. 
Table 2. Prevalence (P), mean abundance $(A)$ and mean intensity (MI) of each rodent according to intrinsic (sex) and extrinsic (landscape) factors in small fragments of Atlantic Forest in western Paraná, Brazil.

\begin{tabular}{|c|c|c|c|c|c|c|c|c|c|c|c|c|}
\hline & \multicolumn{12}{|c|}{ Parameters } \\
\hline & \multicolumn{4}{|c|}{ Prevalence (\%) } & \multicolumn{4}{|c|}{ Range intensity } & \multicolumn{4}{|c|}{ Mean abundance } \\
\hline & Male & Female & Border & Fragment & Male & Female & Border & Fragment & Male & Female & Border & Fragment \\
\hline $\begin{array}{c}\text { Akodon } \\
\text { montensis }\end{array}$ & 55 & 45 & 62.5 & 37.5 & 1 & 1 & 1 & 1 & 0.55 & 0.45 & 0.62 & 0.37 \\
\hline $\begin{array}{l}\text { Rodentolepis } \\
\text { akodontis }\end{array}$ & 5 & 5 & 7.5 & 2.5 & - & 4.5 & 9 & 9 & 0.40 & 0.5 & 0.36 & 0.6 \\
\hline $\begin{array}{c}\text { Angiostrongylus } \\
\text { sp. }\end{array}$ & 2.5 & - & 2.5 & - & 4 & - & 4 & - & 0.18 & 0.22 & 0.16 & 0.26 \\
\hline $\begin{array}{l}\text { Protospirura } \\
\text { numidica } \\
\text { criceticola }\end{array}$ & 5 & 5 & 7.5 & 2.5 & 2.5 & 2.5 & 5 & 5 & 0.22 & 0.27 & 0.2 & 0.33 \\
\hline $\begin{array}{c}\text { Trichofreitasia } \\
\text { lenti }\end{array}$ & 37.5 & 17.5 & 27.5 & 27.5 & 14.13 & 30.28 & 19.27 & 19.27 & 9.63 & 11.7 & 8.48 & 14.3 \\
\hline $\begin{array}{c}\text { Stilestrongylus } \\
\text { aculeata }\end{array}$ & 17.5 & 12.5 & 17.5 & 12.5 & 110.5 & 154.8 & 110.5 & 154.8 & 35.18 & 43 & 30.96 & 51.6 \\
\hline Stilestrongylus eta & 20 & 25 & 22.5 & 22.5 & 107 & 107 & 96.3 & 120.37 & 43.77 & 53.5 & 38.52 & 64.2 \\
\hline Trichuris navonae & 17.5 & 20 & 22.5 & 15 & 4.7 & 4.12 & 3.6 & 5.5 & 1.5 & 1.83 & 1.32 & 2.2 \\
\hline Syphacia alata & 12.5 & 12.5 & 20 & 5 & 26.8 & 26.8 & 16.75 & 67 & 6.09 & 7.44 & 5.36 & 8.93 \\
\hline $\begin{array}{l}\text { Pentastomida } \\
\text { gen. sp. }\end{array}$ & 2.5 & - & - & 2.5 & 1 & - & - & 1 & 0.04 & 0.05 & 0.04 & 0.06 \\
\hline $\begin{array}{l}\text { Stilestrongylus } \\
\text { gracielae }\end{array}$ & 37.5 & 30 & 37.5 & 30 & 97.25 & 97.25 & 77.8 & 97.25 & 53.04 & 64.83 & 46.68 & 77.8 \\
\hline $\begin{array}{l}\text { Euryoryzomys } \\
\text { russatus }\end{array}$ & - & 100 & - & 100 & - & 1 & - & 1 & - & 1 & - & 1 \\
\hline $\begin{array}{c}\text { Stilestrongylus } \\
\text { kaaguyporai }\end{array}$ & - & 100 & - & 100 & - & 13 & - & 13 & - & 13 & - & 13 \\
\hline Thaptomys nigrita & 100 & 0 & 50 & 50 & 1 & - & 1 & 1 & 1 & - & 0.5 & 0.5 \\
\hline Stilestrongylus sp. & 100 & - & 50 & 50 & 21.5 & - & 21.5 & 21.5 & 21.5 & - & 43 & 43 \\
\hline Syphacia criceti & 100 & - & - & 100 & - & 1 & - & 1 & - & 0.5 & - & 0.5 \\
\hline $\begin{array}{l}\text { Oligoryzomys } \\
\text { nigripes }\end{array}$ & 100 & - & 60 & 40 & 1 & - & 1 & 1 & 1 & - & 0.6 & \\
\hline $\begin{array}{c}\text { Trichofreitasia } \\
\text { lenti }\end{array}$ & 40 & - & 20 & 20 & 23.5 & - & 47 & 47 & 9.4 & - & 23.5 & 15.6 \\
\hline $\begin{array}{l}\text { Stilestrongylus } \\
\text { franciscanus }\end{array}$ & 40 & - & 20 & 20 & 92.5 & - & 185 & 185 & 37 & - & 92.5 & 61.6 \\
\hline Mus musculus * & 50 & 35 & - & - & 1 & 1 & - & - & 0.5 & 0.35 & - & - \\
\hline Syphacia criceti & 20 & 25 & - & - & 57.5 & 46 & - & - & 23 & 32.8 & - & - \\
\hline $\begin{array}{l}\text { Syphacia } \\
\text { evaginata }\end{array}$ & 10 & 5 & - & - & 61.5 & 123 & - & - & 12.3 & 17.5 & - & - \\
\hline $\begin{array}{l}\text { Stilestrongylus } \\
\text { aculeata }\end{array}$ & 30 & 25 & - & - & 156.7 & 470 & - & - & 47 & 67.1 & - & - \\
\hline $\begin{array}{c}\text { Rodentolespis } \\
\text { akodontis }\end{array}$ & 10 & 15 & - & - & 15.5 & 10.3 & - & - & 3.1 & 4.42 & - & - \\
\hline
\end{tabular}

*Collected only in plantation areas

In Argentina, Navone et al. (2009) reported four species of parasites in O. nigripes, Panisse et al. (2017) eight species in A. montensis, six species in O. nigripes, seven species in E. russatus and four species in T. nigrita. Panisse et al. (2017) conducted a study in the Missiones region, an area with the same biome and geographically close to the area in 


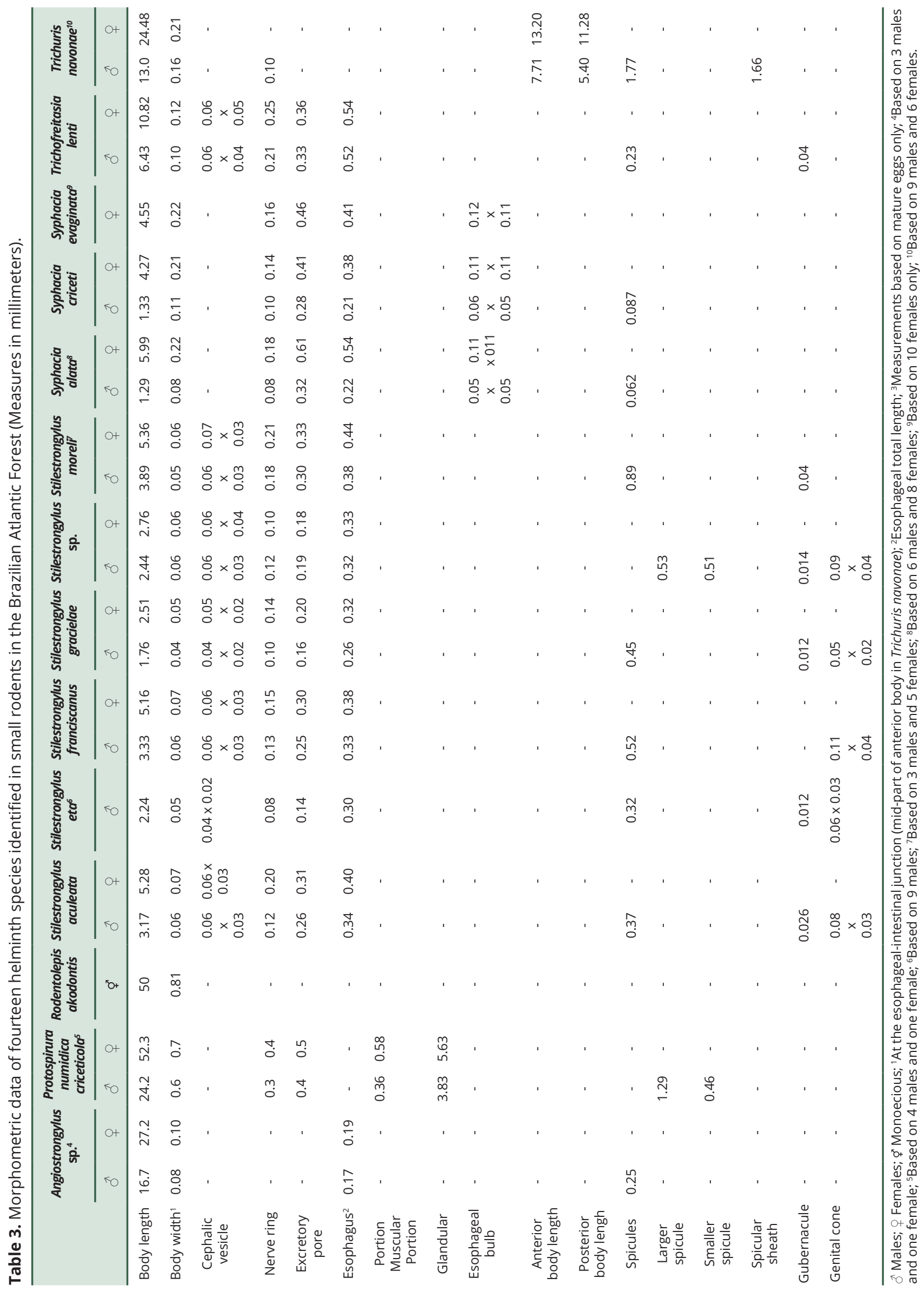




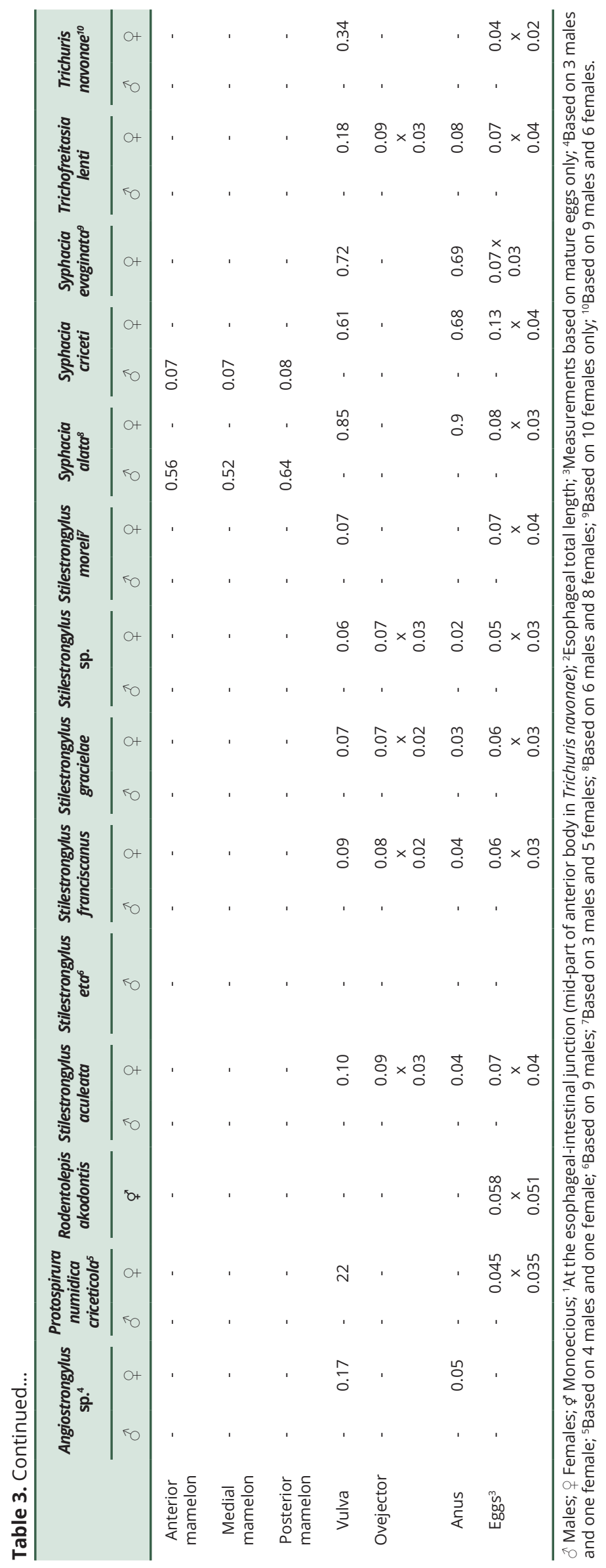


the present study, showing that ecological similarities can influence parasitism and be associated with the range and composition of the host diet as well as with the environmental characteristics of the analyzed areas, as stated by Poulin (2014).

Helminth richness and composition differed among the five rodent species. The observed and estimated richness indices indicated higher average richness in A. montensis (2.77) than in the other host species. Total species richness is dependent on the sample size (Walther et al., 1995) and, in the present study, the sample size was smaller for some rodent species than for A. montensis. According to Poulin (2014), host population density is a determinant of the rates of infection of directly transmitted parasites and can be overestimated or underestimated when the sample size is relatively small. Even when a small number of hosts are analyzed, the results help to understand parasite-host dynamics, such as the structure of the parasite community.

Low similarity was observed among hosts in relation to parasite infra-community (Figure 3). The difference in habitat use, and eating habits (Dalmagro \& Vieira 2005; Cardoso et al., 2016), may have favored host specificity in some helminth species (Poulin, 2014). Parasite sharing is more likely to occur between biologically, ecologically, and/or phylogenetically related host species (Dallas \& Presley 2014; Bellay et al., 2015). In this study, the rodent species are of different genera, this could explain the low similarity of helminth fauna found.

Stilestrongylus aculeata was recovered from rodents of the genus Akodon in the state of Rio de Janeiro (Gomes et al., 2003) and in Argentina (Panisse et al., 2017). Stilestrongylus eta was recorded in the genus Akodon (Durette-Desset \& Digiani, 2010), in Rio de Janeiro state. The species $P$. numidicola criceticola has been found in several hosts, including carnivores (Stein et al., 1994) and rodents (Quentin, 1971; Sutton, 1989; Miño, 2008; Simões et al., 2010). Trichofreitasia lenti nematodes and $R$. akodontis cestodes were previously found to parasitize $A$. montensis in Argentina (Panisse et al., 2017), and Oligoryzomys nigripes in the state of Santa Catarina, Brazil (Boullosa et al., 2019).

Trichuris navonae has been described as parasitizing A. montensis in the Missiones Province, Argentina (Robles, 2011), and in Santa Catarina by Boullosa et al. (2019). Digiani \& Durette-Desset (2007) reported, for the first time, the species S. gracielae parasitizing Phyllotis sp. (Sigmodontinae) in the Province of Catamarca, Argentina. Stilestrongylus franciscanus is described in the intestine of Graomys griseoflavus in the Province of San Luis, Argentina (Digiani \& Durette-Desset, 2003). Stilestrongylus moreli was reported by Panisse \& Digiani, (2018) from the Argentine

\section{Helminth species}

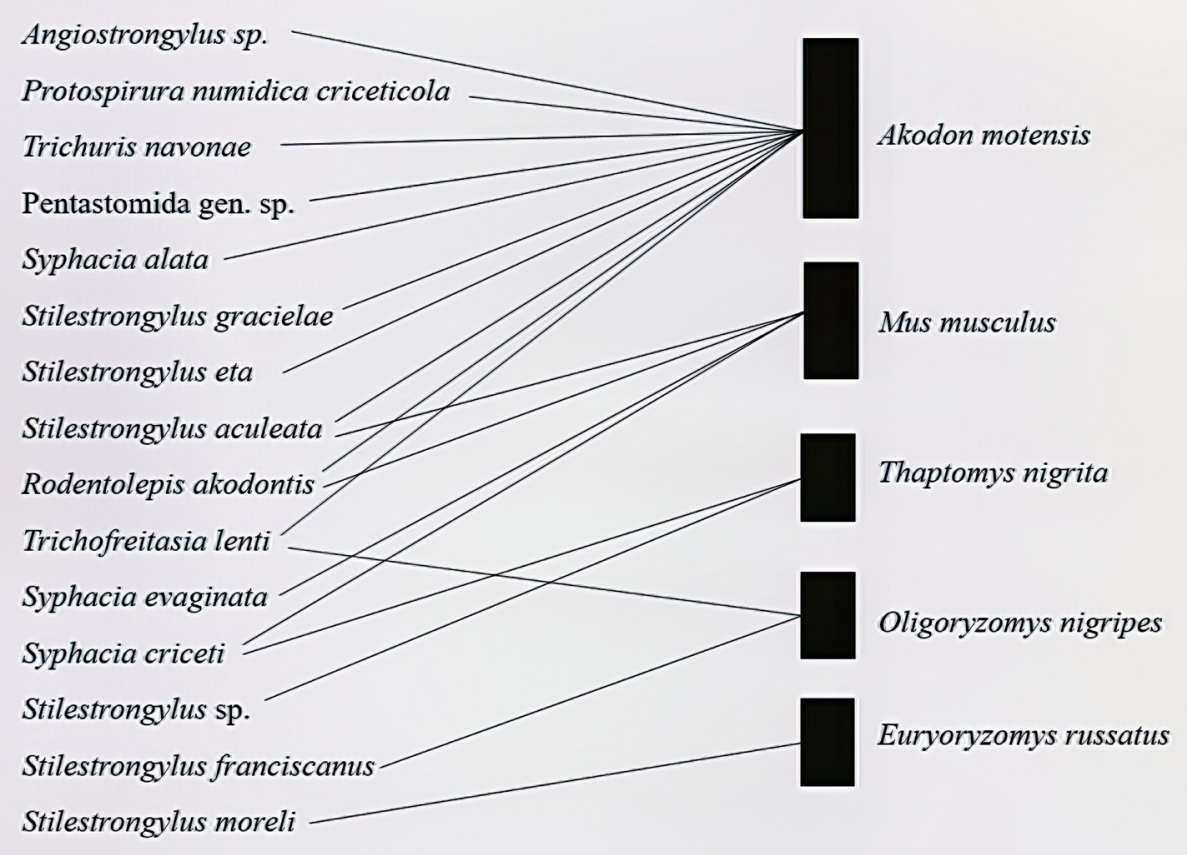

Figure 3. Rodent helminth interaction in five small Atlantic Forest fragments in western Paraná state, Brazil. 
Atlantic Forest, in the Misiones province in the rodent Euryoryzomys russatus. Species of Syphacia are often found parasitizing the cecum of cricetid rodents, mainly sigmodontids (Quentin 1971; Hugot 1988).

Nematodes of the genus Angiostrongylus are parasitize rodents and carnivores, residing in the pulmonary or mesenteric arteries of their hosts (Maldonado-Júnior et al., 2012). Two species are pathogenic in humans: Angiostrongylus cantonensis causes eosinophilic meningitis or meningoencephalitis, and Angiostrongylus costaricensis produces abdominal angiostrongiliasis (Acha \& Szyfres, 2003; Maldonado-Júnior et al., 2012; Spratt, 2015). The Angiostrongylus sp. specimens that were recovered from the pulmonary arteries of $A$. montensis are morphologically compatible with $A$. costaricensis (Figure 3), but further studies are necessary to clarify this. Unfortunately, we obtained four specimens, and only two of them were not fragmented. As preliminary molecular analyses were not compatible with the generic identification (Benatti et al., unpublished data), additional studies will be performed to confirm the specific identity of the parasite. In an isolate of $A$. costaricensis from Costa Rica, Eamsobhana et al. (2010) showed differences compared to a Brazilian isolate, with an uncorrected p-distance of 11.39\%. Jefferies et al. (2009), when comparing isolates of $A$. vasorum from Europe with isolates from South America also showed differences, indicating the possibility of cryptic species.

Pentastomids are parasites of the respiratory system of vertebrates, and most adults are found in the lungs of reptiles, mainly snakes, lizards, and crocodiles (Bush et al., 2001). In rodents, Porocephalus crotali is the most reported species, and the nymph stage can be found in the liver, lung, diaphragm, mesentery, and abdominal cavity (Martínez, 1982). The adult form occurs mainly in crotalines (Esslinger, 1962), suggesting that $A$. montensis is involved in the food chain of local snakes.

The helminthfauna of T. nigrita has been previously described by Panisse et al. (2017) and Cardoso et al. (2018). These authors reported the occurrence of a new unnamed species of the genus Stilestrongylus in Argentina and Brazil. In the present study, the only specimen of Stilestrongylus found in T. nigrita seems to be the same species found by Panisse et al. (2017), based on the morphological characteristics observed.

Exotic parasite populations in M. musculus may originate by transfer from other populations of the same host species or by transfer from other host species in close ecological contact (Tattersall et al., 1994). This could explain the presence of helminths S. aculeata, R. akodontis, and S. criceti, which are most commonly found in wild rodents (Gomes et al., 2003; Panisse et al., 2017). This may be an indication of a spill back event, that is, a parasite, commonly found in native host species, adapting to an exotic host species (Tattersall et al., 1994).

The prevalence and abundance of helminths in wild rodents depend on both extrinsic (temporal, seasonal, and local effects) and intrinsic (age, sex) factors, which interact in various ways to shape the structure of the component community in a given habitat at a specific time (Abu-Madi et al., 2000; Behnke et al., 2005). The age of the host is perhaps the most important of the intrinsic factors, with older or adult animals generally harboring more species of helminths and greater parasitic loading, the so-called cumulative effect (Behnke et al., 1999). In this study, older animals showed greater susceptibility or exposure to Trichuris navonae and Trichofreitasia lenti, demonstrating that older individuals are more at risk due to the longer exposure time (Behnke et al., 1999).

Sympatric host species generally show differences in feeding strategy and habitat occupation or present distinct activity patterns (Simões et al., 2010). Thus, the establishment of parasitic communities is influenced by the diet of these animals, which, in many species, includes small insects that can act as intermediate hosts of the parasites (Reis et al., 2010). Similarly, the composition and use of the landscape is also a determining factor for host populations (Umetsu \& Pardini, 2007; Simões et al., 2010). Some of these factors can be applied to the differences observed in the helminthic community of the analyzed wild rodent population.

This study represents a new location record for all helminth species, extending the geographical distribution of parasites and new host records for Syphacia alata, S. criceti, S. evaginata, Stilestrongylus gracielae, S. franciscanus, S. moreli, S. aculeata, and Rodentolepis akodontis.

\section{Acknowledgements}

This study was financed in part by the Coordenação de Aperfeiçoamento de Pessoal de Nível Superior - Brasil (CAPES) - Finance Code 001 and by the National Council for Scientific and Technological Development - Brazil (CNPq). 


\section{References}

Abu-Madi MA, Behnke JM, Lewis JW, Gilbert FS. Seasonal and site specific variation in the component community structure of intestinal helminths from Apodemus sylvaticus from three contrasting habitats in south-east England. J Helminthol 2000; 74(1): 7-15. http://dx.doi.org/10.1017/S0022149X00000020. PMid:10831048.

Acha PN, Szyfres B. Zoonosis y enfermedades transmisibles comunes al hombre y a los animales. 3rd ed. Washington: Organización Panamericana de la Salud; 2003.

Anderson RC, Chabaud AG, Willmott S. Keys to the nematode parasites of vertebrates: archival volume. Wallingford (UK): CAB International; 2009. http://dx.doi.org/10.1079/9781845935726.0000.

Behnke JM, Gilbert FS, Abu-Madi MA, Lewis JW. Do the helminth parasites of wood mice interact? J Anim Ecol 2005; 74(5): $982-993$. http://dx.doi.org/10.1111/j.1365-2656.2005.00995.x.

Behnke JM, Lewis JW, Zain SNM, Gilbert FS. Helminth infections in Apodemus sylvaticus in southern England: interactive effects of host-age, sex and year on prevalence and abundance of infections. J Helmintho/ 1999; 73(1): 31-44. http://dx.doi.org/10.1017/ S0022149X99000049. PMid:10431369.

Bellay S, Oliveira EF, Almeida-Neto M, Abdallah VD, Azevedo RK, Takemoto RM, et al. The patterns of organisation and structure of interactions in a fish-parasite network of a neotropical river. Int J Parasito/ 2015; 45(8): 549-557. http://dx.doi.org/10.1016/j. ijpara.2015.03.003. PMid:25900213.

Bonvicino CR, Oliveira JA, D'andrea PS. Guia de Roedores do Brasil, com chaves para gêneros baseadas em caracteres externos. Rio de Janeiro: Organização Pan-Americaa da Saúde - OPAS/OMS; 2008.

Boullosa RG, Cardoso TS, Costa-Neto SF, Teixeira BR, Freitas TPT, Arnaldo Maldonado-Júnior A, et al. Helminth community structure of three Sigmodontine Rodents in the Atlantic Forest, southern Brazil. Oecol Aust 2019; 24(2): 301-314. http://dx.doi. org/10.4257/oeco.2020.2403.04.

Brasil. Conselho Federal de Medicina Veterinária - CFMV. Resolução n 1000, de 11 de Maio de 2012. Dispõe sobre procedimentos e métodos de eutanásia em animais, e dá outras providências. Diário Oficial da República Federativa do Brasil [online]. Brasília, 2012 [cited 2019 Apr 4]. Available from: http://www3.cfmv.gov.br/portal/public/lei/index/id/326

Bush AO, Fernández JC, Esch GW, Seed JR. Parasitism: the diversity and ecology of animal parasites. Cambridge: Cambridge University Press; 2001.

Bush AO, Lafferty KD, Lotz JM, Shostak AL. Parasitology meets ecology on its own terms: margolis et al. revisited. J Parasito/ 1997; 83(4): 575-583. http://dx.doi.org/10.2307/3284227. PMid:9267395.

Cardoso TS, Braga CAC, Macabu CE, Simões RO, Costa-Neto SF, Maldonado A Jr, et al. Helminth metacommunity structure of wild rodents in a preserved area of the Atlantic Forest, Southeast Brazil. Rev Bras Parasito/ Vet 2018; 27(4): 495-504. http://dx.doi. org/10.1590/s1984-296120180066. PMid:30427522.

Cardoso TS, Macabu CE, Simões RO, Maldonado A Jr, Luque JL, Gentile R. Helminth community structure of two sigmodontine rodents in Serra dos Órgãos National Park, State of Rio De Janeiro, Brazil. Oecol Aust 2019; 23(2): 301-314. http://dx.doi.org/10.4257/ oeco.2019.2302.09.

Cardoso TS, Simões RO, Luque JLF, Maldonado A Jr, Gentile R. The influence of habitat fragmentation on helminth communities in rodent populations from a Brazilian Mountain Atlantic Forest. J Helmintho/ 2016; 90(4): 460-468. http://dx.doi.org/10.1017/ S0022149X15000589. PMid:26206199.

Dallas T, Presley SJ. Relative importance of host environment, transmission potential and host phylogeny to the structure of parasite metacommunities. Oikos 2014; 123(7): 866-874. http://dx.doi.org/10.1111/oik.00707.

Dalmagro AD, Vieira EM. Patterns of habitat utilization of small rodents in an area of Araucaria forest in Southern Brazil. Austral Ecol 2005; 30(4): 353-362. http://dx.doi.org/10.1111/j.1442-9993.2005.01447.x.

Digiani MC, Durette-Desset MC. Trichostrongylina (Nematoda) parasitic in Phyllotis sp. (Rodentia: Sigmodontinae) from Argentina, with description of three new species. Parasitol Int 2007; 56(1): 9-18. http://dx.doi.org/10.1016/j.parint.2006.10.001. PMid:17129752.

Digiani MC, Durette-Desset MC. Two new species of Nippostrongylinae (Nematoda: Trichostrongylina: Heligmonellidae) from the grey leaf-eared mouse Graomys griseoflavus (Sigmodontinae) in Argentina. Parasite 2003; 10(1): 21-29. http://dx.doi.org/10.1051/ parasite/2003101p21. PMid:12669346.

Durette-Desset MC, Digiani MC. Taxonomic revision of the type specimens of Ethiopian Nippostrongylinae (Nematoda) deposited at the Natural History Museum of London. Zootaxa 2010; 2494(1): 1-28. http://dx.doi.org/10.11646/zootaxa.2494.1.1.

Eamsobhana P, Lim PE, Solano G, Zhang H, Gan X, Yong HS. Molecular differentiation of Angiostrongylus taxa (Nematoda: Angiostrongylidae) by cytochrome c oxidase subunit I (COI) gene sequences. Acta Trop 2010; 116(2): 152-156. http://dx.doi. org/10.1016/j.actatropica.2010.07.005. PMid:20654571. 
Esslinger JH. Morphology of the egg and larva of Porocephalus crotali (Pentastomida). J Parasitol 1962; 48(3): 457-462. http:// dx.doi.org/10.2307/3275216. PMid:13890829.

Fahrig L. Effects of habitat fragmentation on biodiversity. Annu Rev Ecol Evol Syst 2003; 34(1): 487-515. http://dx.doi.org/10.1146/ annurev.ecolsys.34.011802.132419.

Froeschke G, Matthee S. Landscape characteristics influence helminth infestations in a peri-domestic rodent - implications for possible zoonotic disease. Parasit Vectors 2014; 7(1): 393. http://dx.doi.org/10.1186/1756-3305-7-393. PMid:25159989.

Fundação Nacional de Saúde. Manual de controle de roedores. Brasília: Ministério da Saúde, Fundação Nacional de Saúde; 2002.

Gomes DC, Cruz RP, Vicente JJ, Pinto RM. Nematode parasites of marsupials and small rodents from the Brazilian Atlantic Forest in state of Rio de Janeiro, Brazil. Rev Bras Zoo/ 2003; 20(4): 699-707. http://dx.doi.org/10.1590/S0101-81752003000400024.

Guimarães AO, Valença FM, Sousa JBS, Souza SA, Madi RR, Melo CMM. Parasitic and fungal infections in synanthropic rodents in an area of urban expansion, Aracaju, Sergipe State, Brazil. Acta Sci Biol Sci 2014; 36(1): 113-120. http://dx.doi.org/10.4025/ actascibiolsci.v36i1.19760.

Hancke D, Suárez OV. Structure of parasite communities in urban environments: the case of helminths in synanthropic rodents. Folia Parasito/ 2018;65:009. https://doi.org/10.14411/fp.2018.009.

Hugot JP. Les nématodes Syphaciinae parasites de Rongeurs et de Lagomorphes. Taxinomie. Zoogéographie. Évolution. Bull Mus Natl Hist Nat 1988; 141: 1-153.

Instituto Brasileiro de Geografia e Estatística - IBGE. Censo Agropecuário 2017 [online]. Rio de Janeiro: IBGE; 2017 [cited 2019 Apr 10]. Available from: https://censoagro2017.ibge.gov.br/templates/censo_agro/resultadosagro/index.html

Jefferies R, Morgan ER, Shaw SE. A SYBR green real-time PCR assay for the detection of the nematode Angiostrongylus vasorum in definitive and intermediate hosts. Vet Parasitol 2009; 166(1-2): 112-118. http://dx.doi.org/10.1016/j.vetpar.2009.07.042. PMid:19717239.

Klimpel S, Förster M, Schmahl G. Parasite fauna of the bank vole (Clethrionomys glareolus) in an urban region of Germany: reservoir host of zoonotic metazoan parasites? Parasitol Res 2007; 102(1): 69-75. http://dx.doi.org/10.1007/s00436-007-0725-2. PMid:17849150.

Maldonado-Júnior A, Simões R, Thiengo SC. Angiostrongyliasis in the Americas. In: Lorenzo-Morales J. Zoonosis. Rijeka: InTech; 2012. p. 303-320. http://dx.doi.org/10.5772/38632.

Mangini PR, Nicola PA. Captura e marcação de animais silvestres. In: Cullen-Jr L, Rudran R, Valladares-Padua C. Métodos de estudo em biologia da conservação e manejo da vida silvestre. Curitiba: Editora UFPR; 2006. p. 91-124.

Martínez FA. Nymphs of Porocephalus crotali Humboldt, 1808 (Arachnid, Pentastomida) in edentates in Argentina. Bol Chil Parasitol 1982; 37(3-4): 74-75. PMid:7187235.

Miño MH. Infection pattern of the spirurid nematode Protospirura numidica criceticola in the cricetid rodent Akodon azarae on poultry farms of central Argentina. J Helminthol 2008; 82(2): 153-158. http://dx.doi.org/10.1017/S0022149X08912396. PMid:18298867.

Mittermeier RA, Gil PR, Hoffmann M, Pilgrim J, Brooks T, Mittermeier CG, et al. Hotspots revisited: Earth's biologically richest and most endangered terrestrial ecoregions. Mexico City: CEMEX, Conservation International; 2005.

Myers N, Mittermeier RA, Mittermeier CG, da Fonseca GA, Kent J. Biodiversity hotspots for conservation priorities. Nature 2000; 403(6772): 853-858. http://dx.doi.org/10.1038/35002501. PMid:10706275.

Navone GT, Notarnicola J, Nava S, Robles MR, Galliari C, Lareschi M. Arthropods and helminths assemblage in Sigmodontine rodents from wetlands of the Río de La Plata, Argentina. Mastozool Neotrop 2009; 16(1): 121-133.

Panisse G, Digiani MC. A new species of Stilestrongylus (Nematoda, Heligmonellidae) from the Atlantic Forest of Misiones, Argentina, parasitic in Euryoryzomys russatus (Cricetidae, Sigmodontinae). Parasitol Res 2018; 117(4): 1205-1210. http://dx.doi. org/10.1007/s00436-018-5801-2. PMid:29445859.

Panisse G, Robles MDR, Digiani MC, Notarnicola J, Galliari C, Navone GT. Description of the helminth communities of sympatric rodents (Muroidea: Cricetidae) from the Atlantic Forest in northeastern Argentina. Zootaxa 2017; 4337(2): 243-262. http://dx.doi. org/10.11646/zootaxa.4337.2.4. PMid:29242441.

Patton JL, Pardiñas UF, D’Elía G. Mammals of South America: rodents. Vol. 2. Chicago: University of Chicago Press; 2015. http:// dx.doi.org/10.7208/chicago/9780226169606.001.0001.

Poulin R. Parasite biodiversity revisited: frontiers and constraints. Int J Parasito/ 2014; 44(9): 581-589. http://dx.doi.org/10.1016/j. ijpara.2014.02.003. PMid:24607559. 
Quadros J, Monteiro-Filho ELA. Coleta e preparação de pêlos de mamíferos para identificação em microscopia óptica. Rev Bras Zool 2006; 23(1): 274-278. http://dx.doi.org/10.1590/S0101-81752006000100022.

Quentin JC. Morphologie comparée des structures céphaliques et génitales des Oxyures du genre Syphacia. Ann Parasitol Hum Comp 1971; 46(1): 15-60. http://dx.doi.org/10.1051/parasite/1971461015. PMid:5563722.

Rêgo AA. Sôbre alguns Cestódeos parasitos de roedores do Brasil (Cestoda, Cyclophyllidea). Mem Inst Oswaldo Cruz 1967; 65(1): 1-18. http://dx.doi.org/10.1590/S0074-02761967000100001.

Reis NR, Peracchi AL, Rossaneis BK, Fregonezi MN. Técnicas de estudos aplicadas aos mamíferos silvestres brasileiro. Rio de Janeiro: Technical Books Editora; 2010.

Reperant LA, Hegglin D, Tanner I, Fischer C, Deplazes P. Rodents as shared indicators for zoonotic parasites of carnivores in urban environments. Parasitology 2009; 136(3): 329-337. http://dx.doi.org/10.1017/S0031182008005428. PMid:19154652.

Ribeiro MC, Metzger JP, Martensen AC, Ponzoni FJ, Hirota MM. The Brazilian Atlantic forest: how much is left, and how is the remaining forest distributed? Implications for conservation. Bio/ Conserv 2009; 142(6): 1141-1153. http://dx.doi.org/10.1016/j. biocon.2009.02.021.

Robles MR. New species of Trichuris (Nematoda: Trichuridae) from Akodon montensis Thomas, 1913, of the Paranaense Forest in Argentina. J Parasitol 2011; 97(2): 319-327. http://dx.doi.org/10.1645/GE-2434.1. PMid:21506781.

Schulte-Hostedde Al, Zinner B, Millar JS, Hickling GJ. Restitution of mass-size residuals: validating body condition indices. Ecology 2005; 86(1): 155-163. http://dx.doi.org/10.1890/04-0232.

Silva MX, Paviolo A, Tambosi LR, Pardini R. Effectiveness of protected areas for biodiversity conservation: Mammal occupancy patterns in the Iguaçu National Park, Brazil. J Nat Conserv 2018; 41: 51-62. http://dx.doi.org/10.1016/j.jnc.2017.11.001.

Simões R, Gentile R, Rademaker V, D'Andrea P, Herrera H, Freitas T, et al. Variation in the helminth community structure of Thrichomys pachyurus (Rodentia: Echimyidae) in two sub-regions of the Brazilian Pantanal: the effects of land use and seasonality. J Helminthol 2010; 84(3): 266-275. http://dx.doi.org/10.1017/S0022149X09990629. PMid:19849884.

Simões RO, Maldonado-Júnior A, Luque JL. Helminth communities in three sympatric rodents from the Brazilian Atlantic Forest: contrasting biomass and numerical abundance. Braz J Biol 2012; 72(4): 909-914. http://dx.doi.org/10.1590/S151969842012000500018. PMid:23295521.

Simões RO, Souza JGR, Maldonado AJr, Luque JL. Variation in the helminth community structure of three sympatric sigmodontine rodents from the coastal Atlantic Forest of Rio de Janeiro, Brazil. J Helminthol 2011; 85(2): 171-178. http://dx.doi.org/10.1017/ S0022149X10000398. PMid:20701831.

Spratt DM. Species of Angiostrongylus (Nematoda: Metastrongyloidea) in wildlife: a review. Int J Parasitol Parasites WildI 2015; 4(2): 178-189. http://dx.doi.org/10.1016/j.ijppaw.2015.02.006. PMid:25853051.

Stein M, Suriano DM, Novaro AJ. Parasite nematodes from Dusycion griseus (Gray, 1837), D. culpaeus (Molina, 1782) and Conepatus chinga (Molina, 1782) (Mammalia: Carnivora) in Neuquén, Argentina. Systematics and ecology. Bol Chil Parasitol 1994; 49(3-4): 60-65. PMid:7654286.

Sutton CA. Contribution to the knowledge of Argentina's parasitological fauna. XVII. Spirurida (Nematoda) from Neotropical Cricetidae: Physaloptera calnuensis n. sp. and Protospirura numidica criceticola Quentin, Karimi and Rodriguez de Almeida. Bull Mus Natl Hist Nat 1989; 11(1): 61-67.

Tattersall FH, Nowell F, Smith RH. A review of the endoparasites of wild House Mice Mus domesticus. Mammal Rev 1994; 24(2): 61-71. http://dx.doi.org/10.1111/j.1365-2907.1994.tb00135.x.

Travassos L. Contribuições para o conhecimento da fauna helmintolojica brazileira. Mem Inst Oswaldo Cruz 1917; 9(1): 5-62. http://dx.doi.org/10.1590/S0074-02761917000100001.

Umetsu F, Pardini R. Small mammals in a mosaic of forest remnants and anthropogenic habitats - evaluating matrix quality in an Atlantic forest landscape. Landsc Ecol 2007; 22(4): 517-530. http://dx.doi.org/10.1007/s10980-006-9041-y.

Vicente J], Rodrigues H, Gomes DC, Pinto RM. Nematóides do Brasil. Parte V: nematóides de mamíferos. Rev Bras Zool 1997; 14(Suppl 1): 1-452. http://dx.doi.org/10.1590/S0101-81751997000500001.

Walther BA, Cotgreave P, Price RD, Gregory RD, Clayton DH. Sampling effort and parasite species richness. Parasitol Today 1995; 11(8): 306-310. http://dx.doi.org/10.1016/0169-4758(95)80047-6. PMid:15275331

Yamaguti S. Systema Helminthum. Vol. V- Acanthocephala. New York: Interscience Publisher; 1963. 